\title{
Karakterisasi Hidrogeologi Daerah Sekitar Tapak PLTN di Bengkayang, Kalimantan Barat
}

\section{Hydrogeological Characterization of NPP Site Vicinity in Bengkayang, West Kalimantan}

\author{
Adi Gunawan Muhammad*, Rachman Fauzi, Adhika Junara Karunianto, Wira Cakrabuana, Widodo \\ Pusat Riset dan Teknologi Bahan Galian Nuklir - ORTN-BRIN, \\ Jl. Lebak Bulus Raya No. 9, Ps. Jumat, Jakarta 12440, Indonesia \\ *E-mail: adigm@batan.go.id
}

Naskah diterima: 30 September 2021, direvisi: 18 November 2021, disetujui: 29 November 2021

DOI: 10.17146/eksplorium.2021.42.2.6479

\begin{abstract}
ABSTRAK
Evaluasi tapak merupakan tahap penting dalam penentuan lokasi calon tapak PLTN skala komersial di Indonesia. Aspek-aspek yang dikaji dalam evaluasi tapak berdasarkan peraturan yang berlaku antara lain aspek geoteknik dan aspek dispersi zat radioaktif. Untuk mendukung kajian aspek tersebut maka perlu adanya kajian karakterisasi hidrogeologi daerah sekitar tapak. Tujuan penelitian ini adalah menentukan karakteristik hidrogeologi daerah sekitar tapak PLTN di Kabupaten Bengkayang, Provinsi Kalimantan Barat berdasarkan aspek geologi dan geofisika. Metode yang dilakukan adalah pemetaan geomorfologi, pemetaan geologi, pemetaan hidrogeologi, pengukuran geolistrik, serta analisis terpadu. Secara morfologi, daerah penyelidikan dibagi menjadi tiga satuan, yaitu dataran aluvial, bukit terisolasi, dan dataran pantai. Secara stratigrafi, satuan batuan yang ditemukan berurutan dari tua ke muda adalah andesit, granodiorit, diorit, endapan pasir kuarsa, endapan pantai, dan endapan aluvial. Pengukuran geofisika menggunakan metode geolistrik dilakukan pada 12 lintasan dengan masing-masing panjang lintasan $470 \mathrm{~m}$ dan spasi elektroda $10 \mathrm{~m}$. Pada penampang geolistrik ditemukan beberapa anomali pada kompleks batuan beku yang mengalami frakturasi atau tubuh diorit yang menerobos satuan andesit. Nilai anomali ini berkisar antara $300 \Omega \mathrm{m}$ dan $>8000 \Omega \mathrm{m}$. Nilai resistivitas yang sangat rendah $(<30 \Omega \mathrm{m})$ diinterpretasikan sebagai endapan aluvial yang jenuh air dengan ketebalan mencapai $\pm 100 \mathrm{~m}$. Daerah penelitian dapat dibagi menjadi tiga satuan hidrogeologi; akuifer dengan aliran melalui ruang antarbutir kelulusan tinggi, akuifer dengan aliran melalui ruang antarbutir kelulusan sedang, dan akuifug setempat berarti. Secara umum pola aliran tanah bebas mengalir relatif dari SSW ke NNE.
\end{abstract}

Kata kunci: Evaluasi tapak, hidrogeologi, metode geolistrik, resistivitas, PLTN

\begin{abstract}
Site evaluation is an important phase of site selection for commercial-scale nuclear power plants (NPP) in Indonesia. Geotechnical and radioactive material dispersion aspects are some of the aspects which are assessed in site evaluation under provisions of laws and regulations. To support those aspect evaluations, it is necessary to conduct hydrogeological characterization in the vicinity of the NPP site. The purpose of this study is to determine the hydrogeological characteristic of the vicinity of the NPP site in Bengkayang Regency, West Kalimantan Province based on geological and geophysical aspects. The methods of this study consist of geomorphological mapping, geological mapping, hydrogeological mapping, geoelectric measurement, and integrated analysis. The study area consists of three morphological units: alluvial plain, isolated hills, and coastal plain. Stratigraphically, the lithology units of the study area, from the oldest to the youngest, consist of andesite, granodiorite, diorite, quartz sand deposits, coastal deposits, and alluvial deposits. The geophysical measurement used is the geoelectric method which is conducted at 12 electrode arrays with $470 \mathrm{~m}$ length and spacing of $10 \mathrm{~m}$. In the geoelectrical section, it can be seen that several anomalies can be interpreted as the fractured body of igneous rocks or the diorite intrusion in andesite. These anomaly values are ranged from $300 \Omega \mathrm{m}$ to $>8000 \Omega \mathrm{m}$. The relatively low
\end{abstract}


resistivity values $(<30 \Omega m)$ are interpreted as water saturated-alluvial deposits that could have a thickness of $\pm 100 \mathrm{~m}$. There are three hydrogeological units in the study area: aquifers in which flow is intergranular with high permeability, aquifers in which flow is intergranular with moderate permeability, and aquifug of local importance. Generally, the groundwater in the study area flows from SSW to NNE.

Keywords: Site evaluation, hydrogeology, geoelectric method, resistivity, NPP

\section{PENDAHULUAN}

Energi nuklir merupakan salah satu sumber energi alternatif yang jauh lebih efisien dibandingkan sumber energi fosil. Energi nuklir mempunyai potensi besar untuk menjadi tulang punggung energi baru dan terbarukan (EBT) di masa yang akan datang, yang diharapkan dapat menjadi faktor pengungkit yang signifikan dalam pemenuhan energi listrik nasional. Tahap awal penyediaan data infrastruktur suatu Pembangkit Listrik Tenaga Nuklir (PLTN) adalah penilaian kesiapan tapak PLTN yang dilakukan dari tahap pra-survei, survei, dan evaluasi tapak [1].

Evaluasi tapak merupakan tahap penting dalam penentuan lokasi calon tapak PLTN skala komersial di Indonesia. Aspek-aspek yang dikaji dalam evaluasi tapak sesuai peraturan yang berlaku di antaranya adalah aspek geoteknik dan aspek dispersi zat radioaktif. Aspek dispersi zat radioaktif mengkaji alur lepasan radionuklida melalui atmosfer, air permukaan, dan air tanah (hidrogeologi), sedangkan aspek geoteknik mengkaji aspek keteknikan material batuan/tanah. Kajian aspek geoteknik membutuhkan dukungan data bawah permukaan yang terpadu.

Air tanah sangat spesifik dan unik, kadang keberadaannya tidak merata sehingga untuk mengetahui keberadaan air tanah perlu dilakukan penyelidikan geologi bawah permukaan [2]. Hidrogeologi merupakan kajian geologi yang membahas keberadaan air di bawah permukaan tanah. Manfaat studi hidrogeologi minimal dapat dilihat pada tiga hal, yaitu lingkungan, kebencanaan, dan geoteknik. Dalam hal lingkungan, hasil studi hidrogeologi dapat memberikan data acuan untuk pemanfaatan sumber daya air bawah permukaan. Dalam hal kebencanaan, hasil studi hidrogeologi dapat dikembangkan menjadi strategi/manajemen mitigasi bencana alam untuk pemerintah dan masyarakat. Dalam hal geoteknik, hasil studi hidrogeologi dapat menjadi referensi terkait kesesuaian struktur bangunan terhadap kondisi geologi bawah permukaan di sekitar tapak.

Berdasarkan beberapa hal di atas, maka dalam evaluasi tapak PLTN perlu dilakukan kajian karakterisasi hidrogeologi di daerah sekitar tapak, khususnya pada daerah dalam radius kurang dari $5 \mathrm{~km}$. Penelitian ini bertujuan untuk menentukan karakteristik hidrogeologi daerah sekitar tapak PLTN di Kabupaten Bengkayang, Provinsi Kalimantan Barat berdasarkan aspek geologi dan geofisika. Lokasi penelitian secara administratif terletak di Desa Sungai Raya, Desa Karimunting, dan Desa Sungai Keran, Kecamatan Sungai Raya Kepulauan, Kabupaten Bengkayang, Provinsi Kalimantan Barat (Gambar 1). 


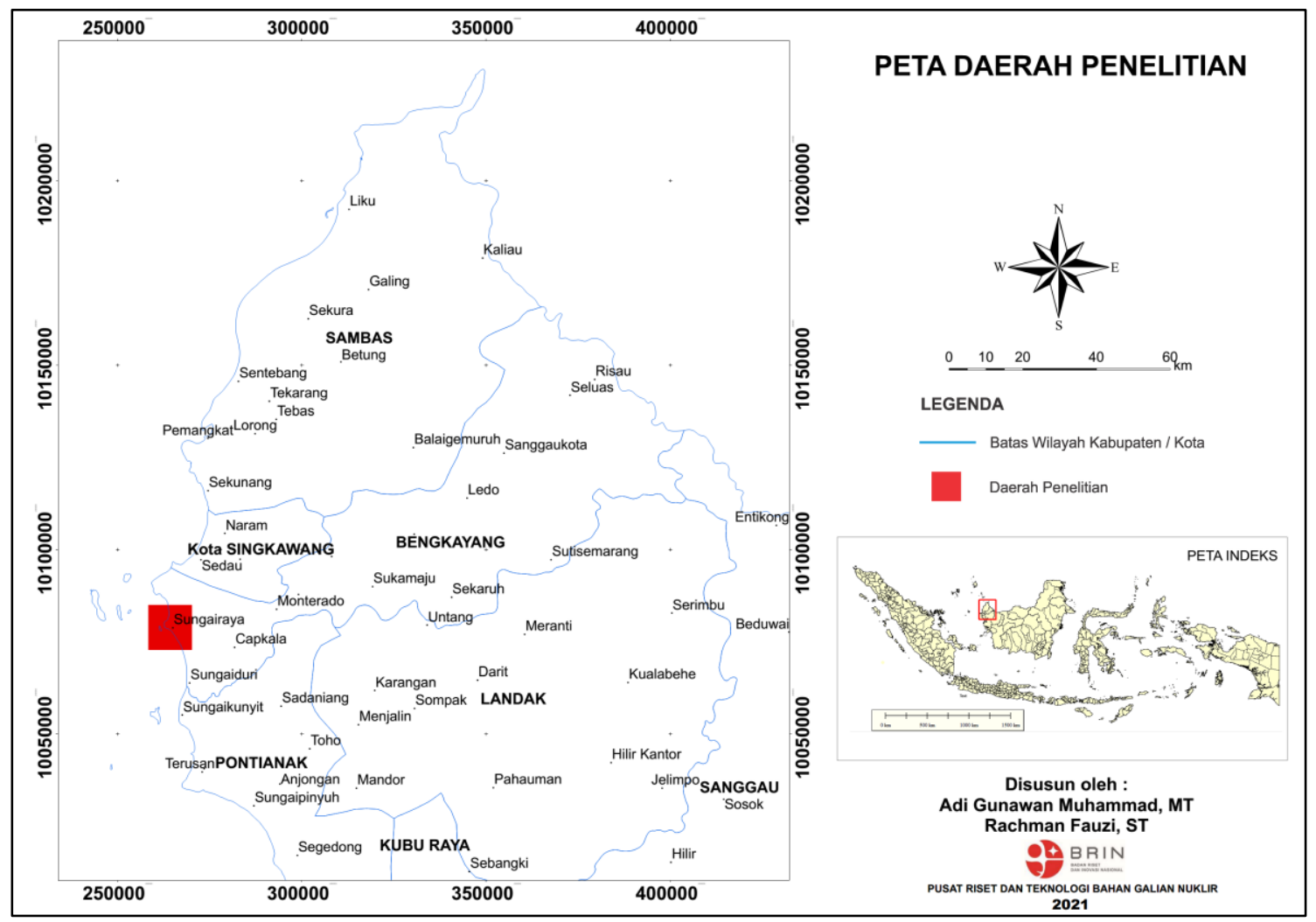

Gambar 1. Peta daerah penelitian di Kalimantan Barat (kotak merah)

\section{METODOLOGI}

Penelitian ini dilakukan dengan menggunakan beberapa metode yang dilaksanakan di studio dan lapangan, yaitu studi pustaka, pemetaan geomorfologi, pemetaan geologi, pemetaan hidrogeologi, pengukuran geofisika, serta analisis terpadu.

Studi pustaka dilakukan dengan mengkaji penelitian terdahulu dan literatur lain yang terkait dengan tujuan penelitian ini. Pemetaan geomorfologi dilakukan untuk mengidentifikasi bentuk, material, dan genesis yang memengaruhi bentuk bentang alam saat ini [3]. Pemetaan geologi dan hidrogeologi dilakukan untuk mengidentifikasi sebaran jenis batuan; struktur geologi primer dan sekunder; serta sebaran sumur gali, mata air, dan sungai. Hasil pemetaan geologi dan hidrogeologi ini digunakan sebagai dasar pertimbangan dalam melakukan analisis dan evaluasi hasil pengukuran geofisika.
Pengukuran geofisika dilakukan dengan metode geolistrik. Metode geolistrik merupakan metode geofisika yang digunakan untuk menyelidiki kondisi bawah permukaan dengan memanfaatkan sifat kelistrikan/ resistivitas batuan [4]. Analisis terpadu merupakan penelaahan secara komprehensif terhadap semua data yang diperoleh untuk diolah menjadi peta geologi, peta hidrogeologi, dan peta kontur elevasi muka air tanah.

\section{GEOLOGI DAN HIDROGEOLOGI REGIONAL}

Kabupaten Bengkayang merupakan salah satu daerah yang memiliki potensi untuk dijadikan lokasi tapak PLTN [5]. Beberapa penelitian tentang penentuan lokasi tapak PLTN di Kalimantan Barat telah dilakukan berdasarkan data sekunder geologi yang bersifat regional [6]-[8]. Berdasarkan hasil penelitian tersebut, lokasi yang paling 
potensial untuk dijadikan tapak PLTN adalah daerah di sepanjang pesisir barat Kabupaten Bengkayang.

Daerah penelitian, sesuai Peta Geologi Regional Lembar Singkawang [9], terdiri atas beberapa formasi batuan yang berumur Kapur hingga Kuarter. Formasi batuan secara berurutan dari tua ke muda adalah sebagai berikut (Gambar 2): Batuan Gunungapi Raya
(Klr) berumur Kapur, tersusun atas andesit, dasit, basal; Batuan Terobosan Sintang (Toms) berumur Oligosen, tersusun atas diorit, mikrodiorit, granodiorit, diorit kuarsa, gabbro kuarsa, dan tonalit; Endapan Litoral (Qc) berumur Kuarter, tersusun atas kerikil, pasir, dan lumpur; Endapan Aluvial dan Rawa (Qa) berumur Kuarter, tersusun atas lumpur, pasir, kerikil, dan sisa tumbuhan.

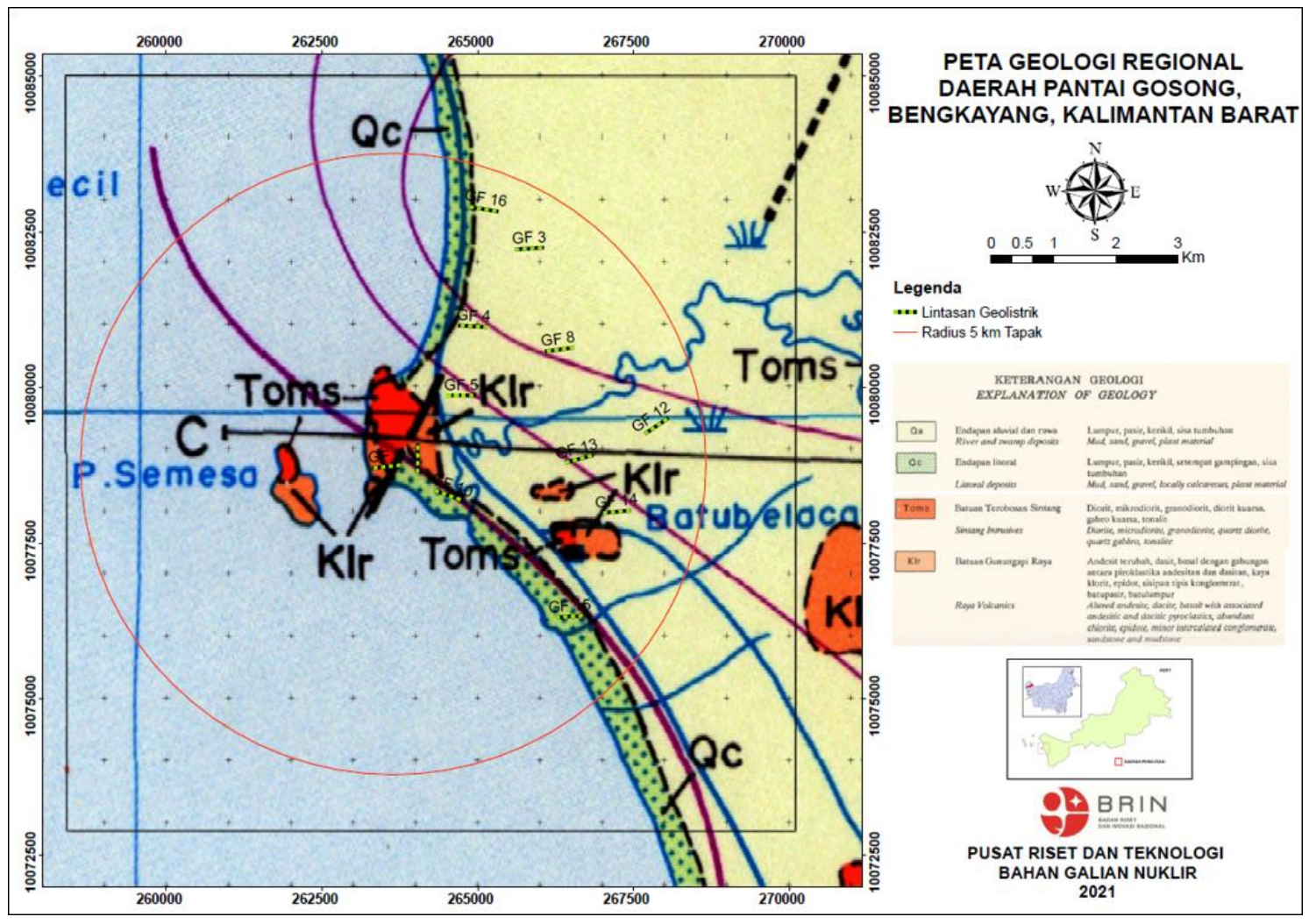

Gambar 2. Peta Geologi Regional Daerah Penelitian (modifikasi dari [9])

Berdasarkan peta geologi regional [9], terdapat indikasi kelurusan struktur geologi yang berkembang di sekitar calon tapak PLTN. Kelurusan terdapat pada batuan vulkanik dan plutonik dengan arah relatif timurlaut-baratdaya. Selain itu, terdapat pula sekumpulan kekar yang memiliki arah relatif timurlaut-baratdaya. Struktur geologi regional ini sangat dipengaruhi oleh adanya Batolit Singkawang yang berupa tanjung di bagian baratlaut [10]. Terdapat sesar berumur
Oligosen (23,7-30 juta tahun yang lalu) di Kota Singkawang dan Kabupaten Bengkayang yang memotong Formasi Sintang, dikenal sebagai Sesar Adang yang bertipe mendatar sinistral [11].

Berdasarkan Peta Hidrogeologi Lembar Sambas dan Singkawang [12], daerah radius $5 \mathrm{~km}$ dari tapak terdiri atas dua satuan hidrogeologi, yaitu akuifer produktif setempat dan akuifer produktif sedang (Gambar 3). 


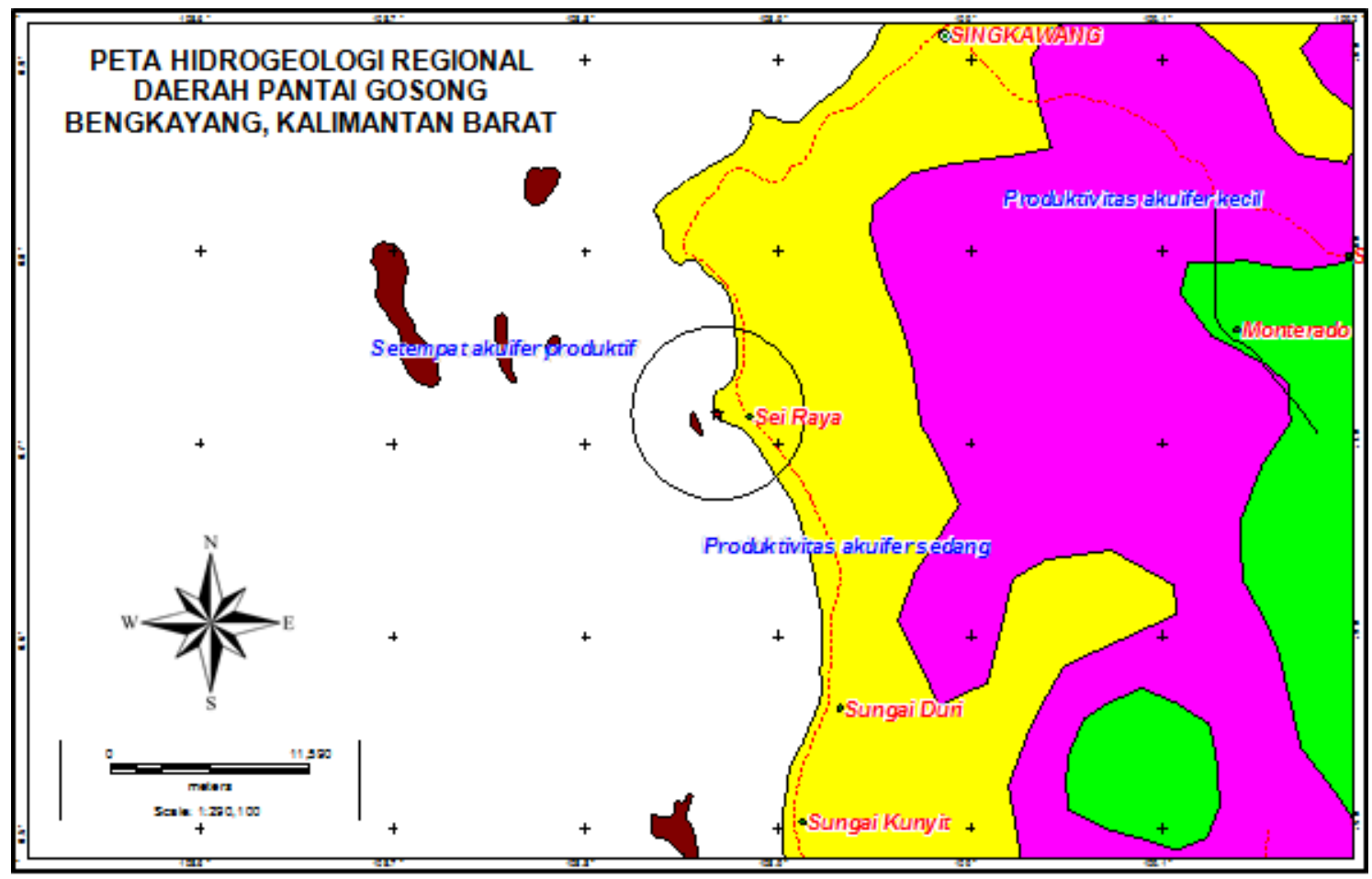

Gambar 3. Peta Hidrogeologi Regional Daerah Penelitian (modifikasi dari [12])

HASIL DAN PEMBAHASAN

\section{Geomorfologi Daerah Penelitian}

Pemetaan geomorfologi memberikan informasi tataan bentukan alam, seperti asosiasi bentuk lahan yang sangat penting dalam pemahaman bentuk lahan dan bentang alam dalam skala individu [13]. Secara morfologi, berdasarkan Klasifikasi Bentuk Muka Bumi (2006), daerah penyelidikan terbagi dalam tiga satuan, yaitu Dataran Aluvial, Bukit Terisolasi, dan Dataran Pantai (Gambar 4)

Satuan morfologi Dataran Aluvial menempati sekitar $87 \%$ dari seluruh luas daerah penyelidikan dengan pola kontur renggang. Elevasi rata-rata satuan ini berkisar antara 5-15 m. Satuan ini terdiri atas daerah bantaran banjir (flood plain) dan rawa-rawa yang meliputi hampir seluruh bagian timur daerah penelitian. Satuan ini umumnya tersusun atas material lepas berukuran lempung hingga pasir-kerikil yang merupakan hasil erosi dan sedimentasi sungai.
Satuan morfologi Bukit Terisolasi menempati bagian barat-tengah daerah penelitian dengan luas pelamparan sekitar 6\%. Elevasi satuan ini berkisar antara 0-170 $m$ dengan pola kontur rapat-agak rapat dan kemiringan lereng $8-26^{\circ}$. Puncak tertinggi berada di Bukit Pekong, Desa Sungai Raya dengan ketinggian mencapai $170 \mathrm{~m}$. Batuan penyusun morfologi ini terdiri atas batuan vulkanik dan batuan terobosan.

Satuan morfologi Dataran Pantai memiliki pelamparan sekitar $7 \%$, berada pada bagian barat daerah penelitian dengan elevasi berkisar 0-7 $\mathrm{m}$ dengan pola kontur sangat renggang. Satuan ini tersusun atas lumpur dan lempung-pasir kasar yang belum terkonsolidasi yang berasal dari erosi dan sedimentasi pantai. Pada daerah hutan bakau dan daerah pasang surut, satuan ini didominasi oleh lumpur. 


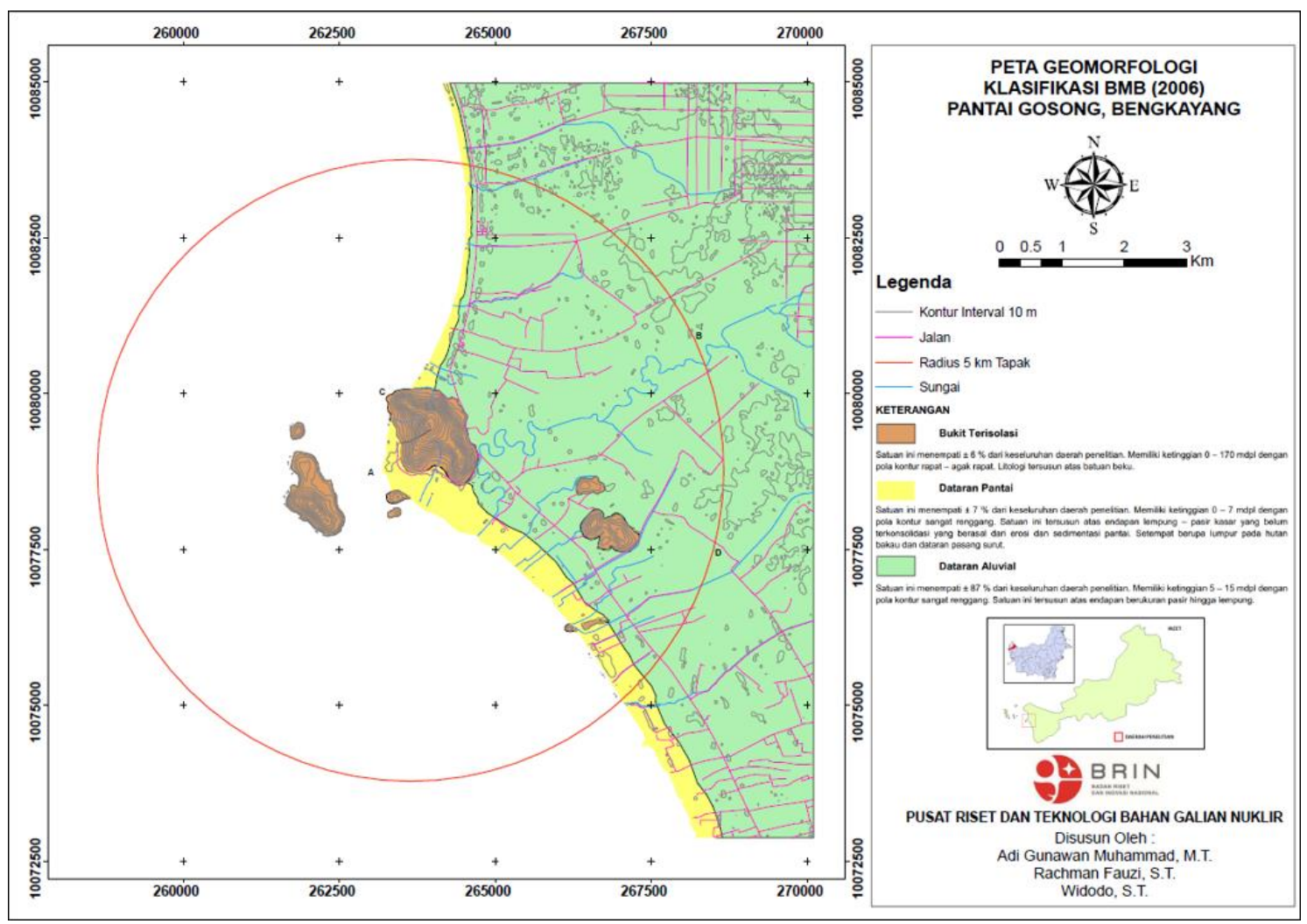

Gambar 4. Peta Geomorfologi Klasifikasi Bentuk Muka Bumi (2006) Daerah Penelitian

\section{Geologi Daerah Penelitian}

Berdasarkan hasil pemetaan geologi secara stratigrafi satuan batuan yang menyusun daerah penelitian, secara berurutan dari tua ke muda, adalah Satuan Andesit, Granodiorit, Diorit, Endapan Pasir Kuarsa, Endapan Pantai, dan Endapan Aluvial (Gambar 5 dan 6).

Satuan Andesit tersingkap di bagian barat dan tengah peta. Secara megaskopis, andesit berwarna segar abu-abu terang, tekstur afanitik-porfiroafanitik, struktur masif, kompak, inekuigranular, subhedral, ekstrusif, komposisi terdiri atas kuarsa, plagioklas, dan sedikit mineral mafik. Setempat ditemukan basal yang hadir sebagai xenolith dalam andesit dengan warna abu-abu gelap, struktur masif, kompak, tekstur afanitik, tersusun atas plagioklas, piroksen, dan mineral mafik.

Granodiorit merupakan batuan plutonik yang menerobos Satuan Andesit. Pada singkapan, batuan ini berwarna lapuk abu-abu kecokelatan, berwarna segar abu-abu dan cokelat kemerahan, holokristalin, tekstur porfiritik, struktur masif, ekuigranular, komposisi tersusun atas plagioklas, kuarsa, K-feldspar, dan biotit.

Satuan Diorit berumur lebih muda dari Satuan Andesit. Pada beberapa singkapan, terlihat jelas diorit hadir mengisi rekahan dalam andesit. Diorit berwarna lapuk cokelat kemerahan, berwarna segar abu-abu keputihan, holokristalin, tekstur fanerik, struktur masif, kompak, ekuigranular, komposisi tersusun atas plagioklas, hornblende, piroksen, dan sedikit kuarsa.

Endapan pasir kuarsa tersebar di bagian timur daerah penelitian. Secara umum endapan pasir kuarsa ini berwarna putih cerah kecokelatan, berukuran butir pasir sedang, pemilahan baik, kemas tertutup, bentuk butiran membulat tanggung, belum tersementasi, komposisi tersusun atas silika berukuran pasir sedang. Endapan pantai 
terletak di sepanjang pesisir barat daerah penelitian. Satuan ini tersusun atas material berukuran butir lempung-pasir kasar yang belum terkonsolidasi yang berasal dari erosi dan sedimentasi pantai. Pada daerah hutan bakau dan daerah pasang surut, satuan ini didominasi oleh lumpur. Endapan aluvial umumnya tersusun atas material lepas berukuran lempung hingga pasir-kerikil hasil erosi sungai yang terletak di daerah bantaran banjir (flood plain) dan rawa yang meliputi hampir seluruh bagian daerah penelitian.

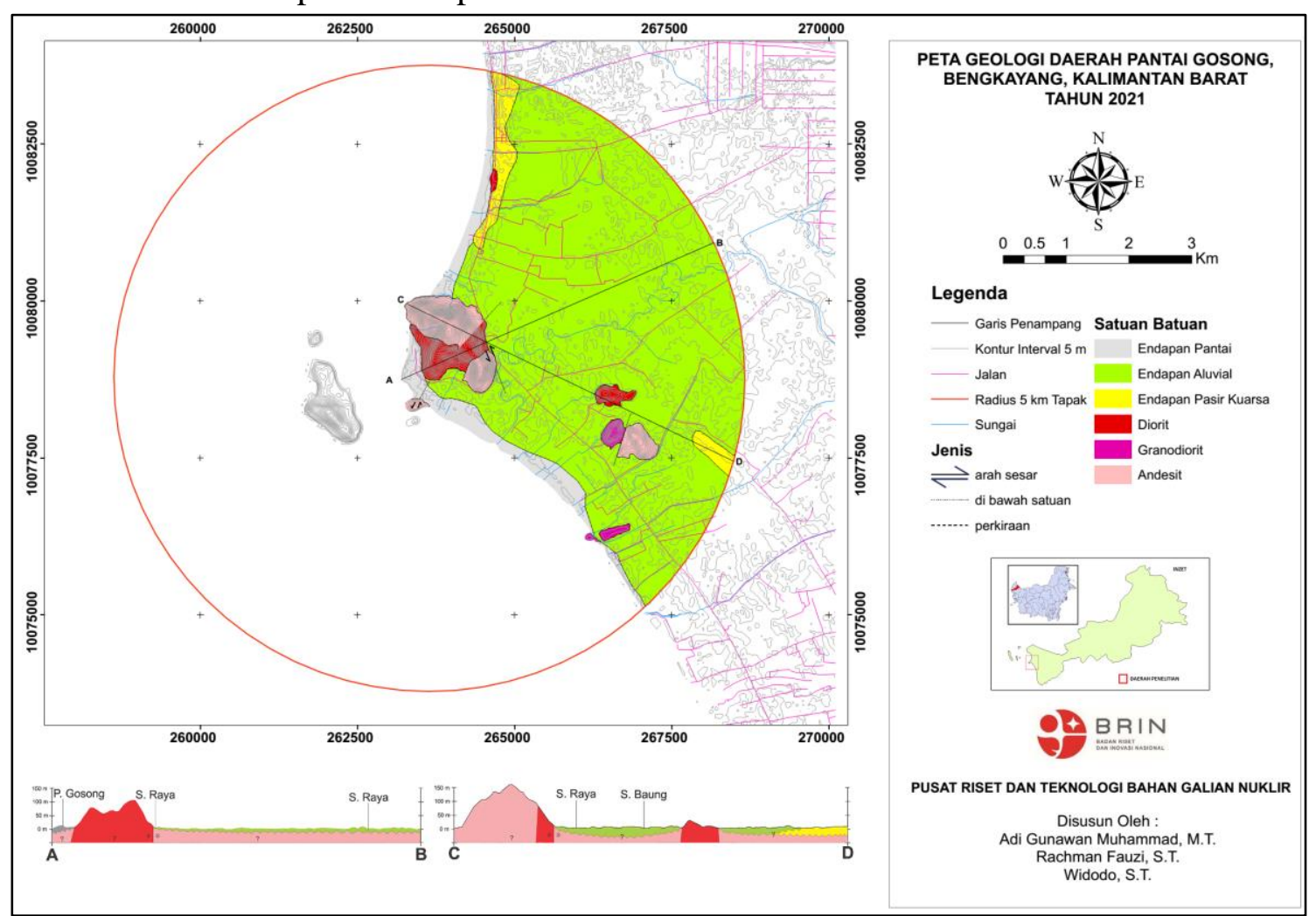

Gambar 5. Peta Geologi Daerah Penelitian

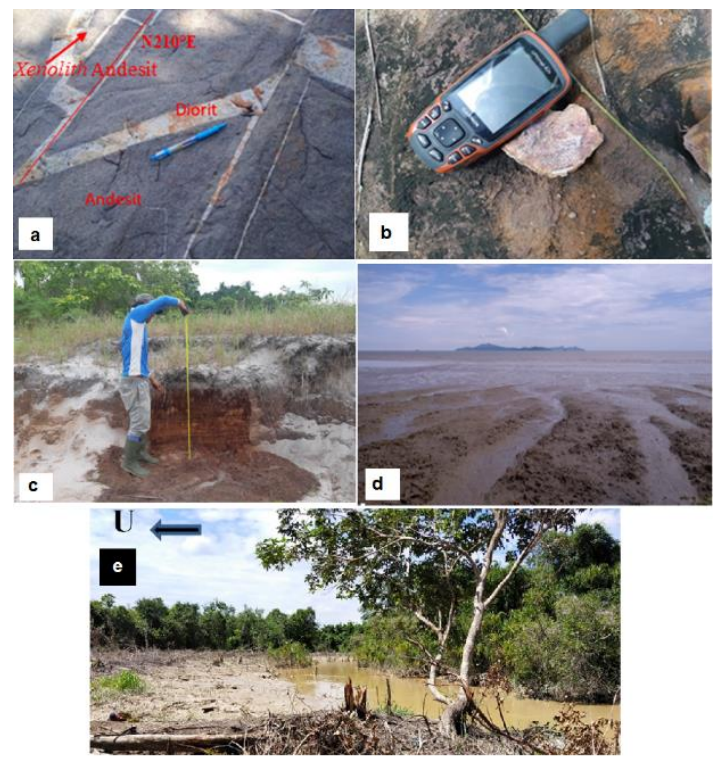

Gambar 6. Foto Singkapan Satuan Batuan: a. Intrusi Diorit pada Andesit, b. Granodiorit, c. Endapan Pasir Kuarsa, d. Endapan Pantai, e. Endapan Aluvial 
Indikasi tektonik di daerah penelitian dikenali berdasarkan pola kelurusan, sebaran mata air dan bentukan morfologi. Berdasarkan indikasi tektonik berupa fraktur (rekahan), diketahui bahwa pengaruh produk tektonik utama di area ini berupa fraktur berarah SSW-NNE dan NNW-ESE. Beberapa elemen struktur tua dengan arah $\mathrm{N} 210^{\circ} \mathrm{E}$ dan $\mathrm{N} 340^{\circ} \mathrm{E}$ dijumpai pada batuan beku andesit yang berumur Kapur Awal dan telah terisi oleh diorit. Hal ini mengindikasikan diorit hadir setelah andesit yang menerobos batuan andesit yang telah terbentuk sebelumnya.

\section{Pengukuran Geolistrik}

Dari semua metode geofisika, metode geolistrik telah lazim diterapkan pada investigasi air tanah [14]. Setiap batuan memiliki daya hantar listrik dan nilai resistivitas yang berbeda. Faktor-faktor yang mempengaruhi hal tersebut antara lain: komposisi litologi, kondisi batuan, komposisi mineral, kandungan fluida, dan faktor eksternal lainnya [15].

Pengukuran geofisika menggunakan metode geolistrik dilakukan pada 12 lintasan dengan masing-masing panjang lintasan 470 $\mathrm{m}$ dan spasi elektroda $10 \mathrm{~m}$ (Gambar 7 dan 8). Pada penampang geolistrik ditemukan beberapa anomali yang ditunjukkan oleh nilai resistivitas $>300 \Omega \mathrm{m}$. Anomali diinterpretasikan sebagai kompleks batuan beku yang mengalami frakturasi. Hal tersebut dapat dilihat pada beberapa penampang, misalnya GF-06 (Gambar 8), terlihat indikasi nilai rendah di sekitar patok 33 yang diinterpretasikan sebagai andesit yang mengalami frakturasi kemudian bidangbidang frakturasi tersebut terisi oleh air tawar/ asin sehingga memberikan respon nilai resistivitas yang lebih rendah jika dibandingkan dengan andesit atau batuan beku lainnya yang masih segar. Hal tersebut juga teramati di lapangan berupa sistem frakturasi berarah $\mathrm{N} 210^{\circ} \mathrm{E}$ yang terisi diorit, serta diduga menerus hingga lokasi GF-06.

Pada penampang geolistrik lain, seperti GF-10, GF-13, GF-12, GF-14, GF-16, dan GF-17, dijumpai indikasi adanya tubuh batuan beku dengan resistivitas yang relatif tinggi di bawah massa batuan yang memiliki nilai resistivitas rendah (Gambar 8). Nilai anomali ini berkisar antara 300-8.000 $\Omega \mathrm{m}$. Tubuh andesit diinterpretasikan memiliki nilai resistivitas $300 \Omega \mathrm{m}$ hingga $2000 \Omega \mathrm{m}$ sedangkan tubuh diorit memiliki nilai resistivitas lebih dari $2000 \Omega \mathrm{m}$.

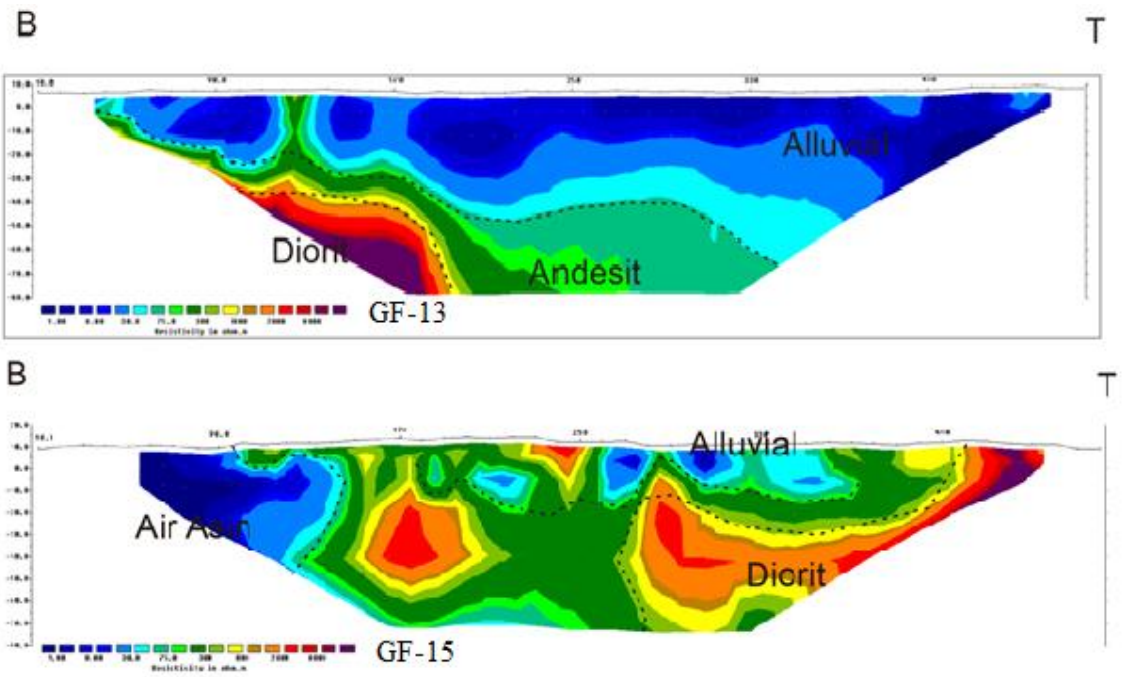

Gambar 7. Penampang geolistrik tahanan jenis di lokasi GF-13 dan GF-15. 


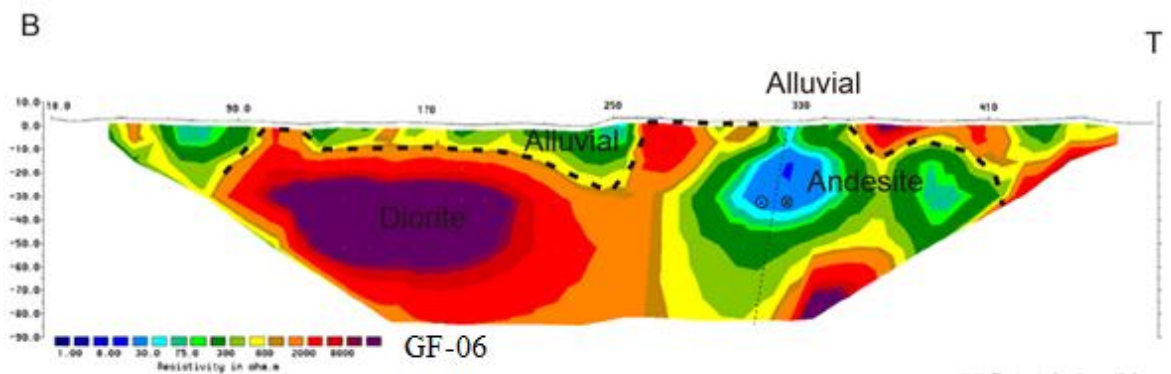

$\mathrm{T}$

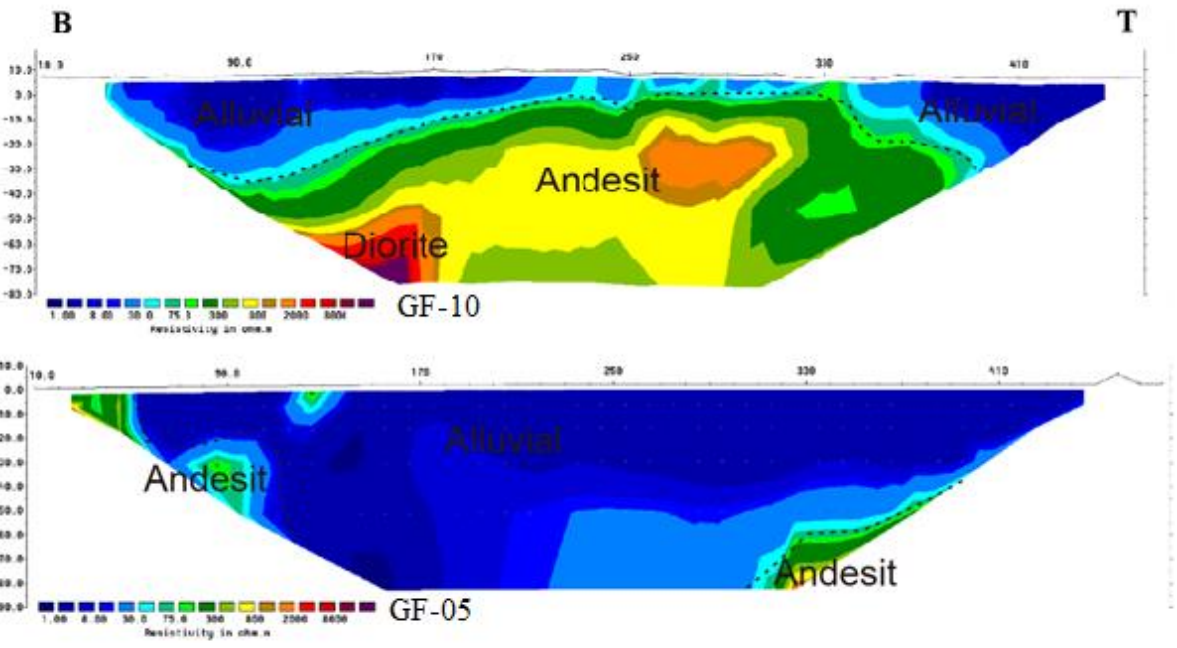

Gambar 8. Penampang geolistrik tahanan jenis di lokasi GF-05, GF-06, dan GF-10.

Nilai resistivitas yang sangat rendah $(<30$ $\Omega \mathrm{m})$ diinterpretasikan sebagai endapan aluvial yang jenuh air. Pada beberapa penampang, seperti GF-04, GF-05, GF-08, dan GF-03, ketebalan endapan aluvial dapat mencapai $\pm 100 \mathrm{~m}$ (Gambar 8). Adanya pengaruh intrusi air asin juga terlihat pada penampang GF-15 (Gambar 7). Tampak di bagian barat penampang yang merupakan pesisir pantai terdapat zona dengan nilai resistivitas yang rendah. Zona tersebut diinterpretasikan sebagai batuan yang mengalami pelapukan kemudian air asin mengisi pori atau celah yang ada.

\section{Hidrogeologi Daerah Penelitian}

Berdasarkan hasil pemetaan hidrogeologi yang ditunjang dengan data pemetaan geologi dan pengukuran geolistrik diperoleh informasi bahwa sistem air tanah daerah penelitian dapat dikelompokkan menjadi dua sistem sebagai berikut:

- Sistem akuifer dengan aliran air tanah melalui ruang antarbutir, memiliki permeabilitas tinggi. Sistem ini banyak terdapat pada Satuan Endapan Pasir Kuarsa.

- Sistem akuifer dengan aliran air tanah melalui ruang antarbutir, memiliki permeabilitas sedang. Sistem ini dijumpai pada Satuan Endapan Aluvial yang secara umum tersusun atas material lepas berukuran lempung hingga pasir-kerikil hasil erosi sungai.

Berdasarkan kemampuan batuan/tanah/ produk pelapukan batuan dalam menyimpan dan meluluskan air, maka batuan/tanah/ produk pelapukan batuan di lokasi ini dapat dikelompokkan menjadi dua, yaitu kelompok akuifer dan kelompok non akuifer/akuifug. 
Kelompok akuifer tersusun atas Satuan Endapan Pasir Kuarsa dan Satuan Endapan Aluvial yang memiliki permeabilitas sedangtinggi. Satuan Endapan Pasir Kuarsa cenderung memiliki permeabilitas lebih tinggi jika dibandingkan dengan Satuan Endapan Aluvial karena memiliki pemilahan yang lebih bagus. Kelompok Non-Akuifer/Akuifug tersusun atas batuan dasar yang bersifat kedap air. Contoh akuifug di lokasi ini adalah batuan beku vulkanik dan plutonik, yaitu andesit, diorit, dan granodiorit. Pada kelompok ini, air tanah dengan jumlah terbatas dapat dijumpai pada daerah lembah atau zona pelapukan dan potensinya bisa meningkat pada daerah atau zona batuan yang mengalami frakturasi.

Batas-batas dan sebaran kelompok satuan hidrogeologi daerah penelitian disajikan pada Gambar 9. Berdasarkan peta dan penampang hidrogeologi yang disajikan, terlihat bahwa daerah penelitian merupakan subcekungan air tanah dengan tinggian berada pada sisi barat. Kompleks batuan beku umumnya berupa akuifug, namun pada beberapa lokasi terdapat banyak mata air yang keberadaannya dikontrol oleh rekahan pada batuan (akuifer celah). Selain itu, air tanah dengan jumlah terbatas juga dapat dijumpai pada lembah atau pada zona pelapukan batuan beku.

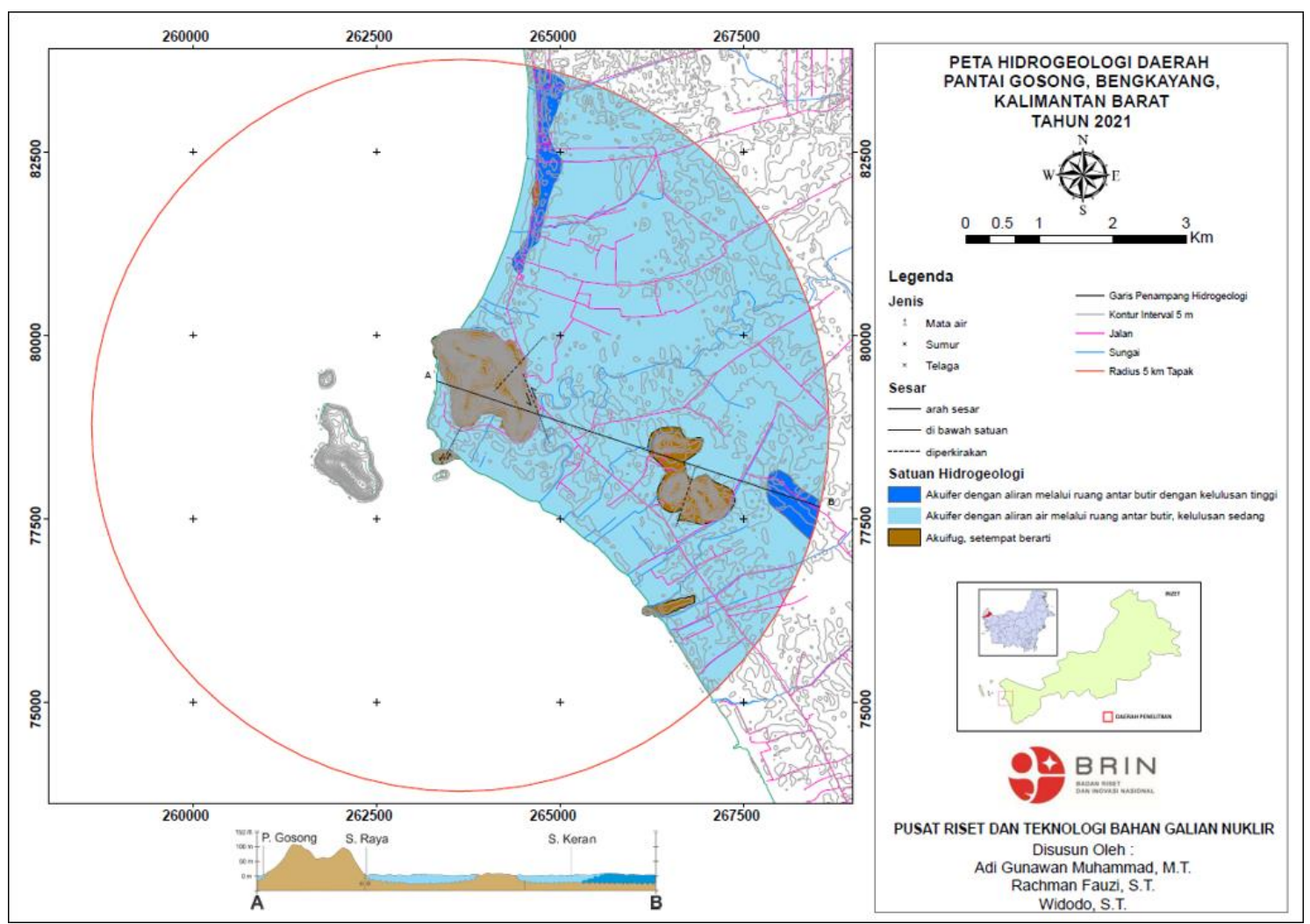

Gambar 9. Peta Hidrogeologi Daerah Penelitian

Di daerah penelitian dijumpai sungaisungai kecil yang bermuara ke sungai utama, yaitu Sungai Raya yang kemudian mengalir relatif berarah NNE-WSW dan bermuara akhir di Selat Karimata. Proses erosi pada sungai utama diinterpretasikan sudah memasuki stadium tua, diindikasikan dengan dominasi erosi lateral sehingga penampang sungai menyerupai bentuk "U" serta alur sungai yang sudah berkelok-kelok atau meander. Berdasarkan stadium erosi tersebut, sungaisungai yang mengalir pada morfologi ini 
sangat berperan dalam mengisi air tanah (influent stream). Pengukuran debit air pada beberapa sungai yang ada menghasilkan nilai 0,24-242,8 1/dtk.

Pengukuran elevasi muka air tanah (MAT) dilaksanakan dengan mendata sumur gali yang ada di rumah penduduk di daerah penelitian. Data yang diambil berupa data kedalaman sumur. Dari data yang diperoleh, dapat diketahui elevasi MAT di lokasi sekitar tapak. Histogram data MAT sumur gali dapat dilihat pada Gambar 10. Peta Kontur Elevasi MAT dapat dilihat pada Gambar 11.

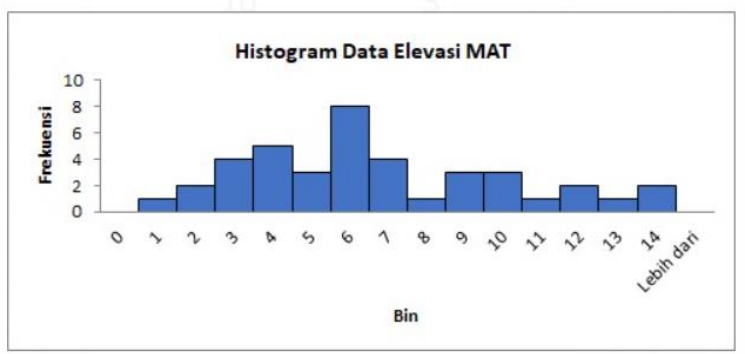

Gambar 10. Histogram Data MAT dari Pengukuran Sumur Gali

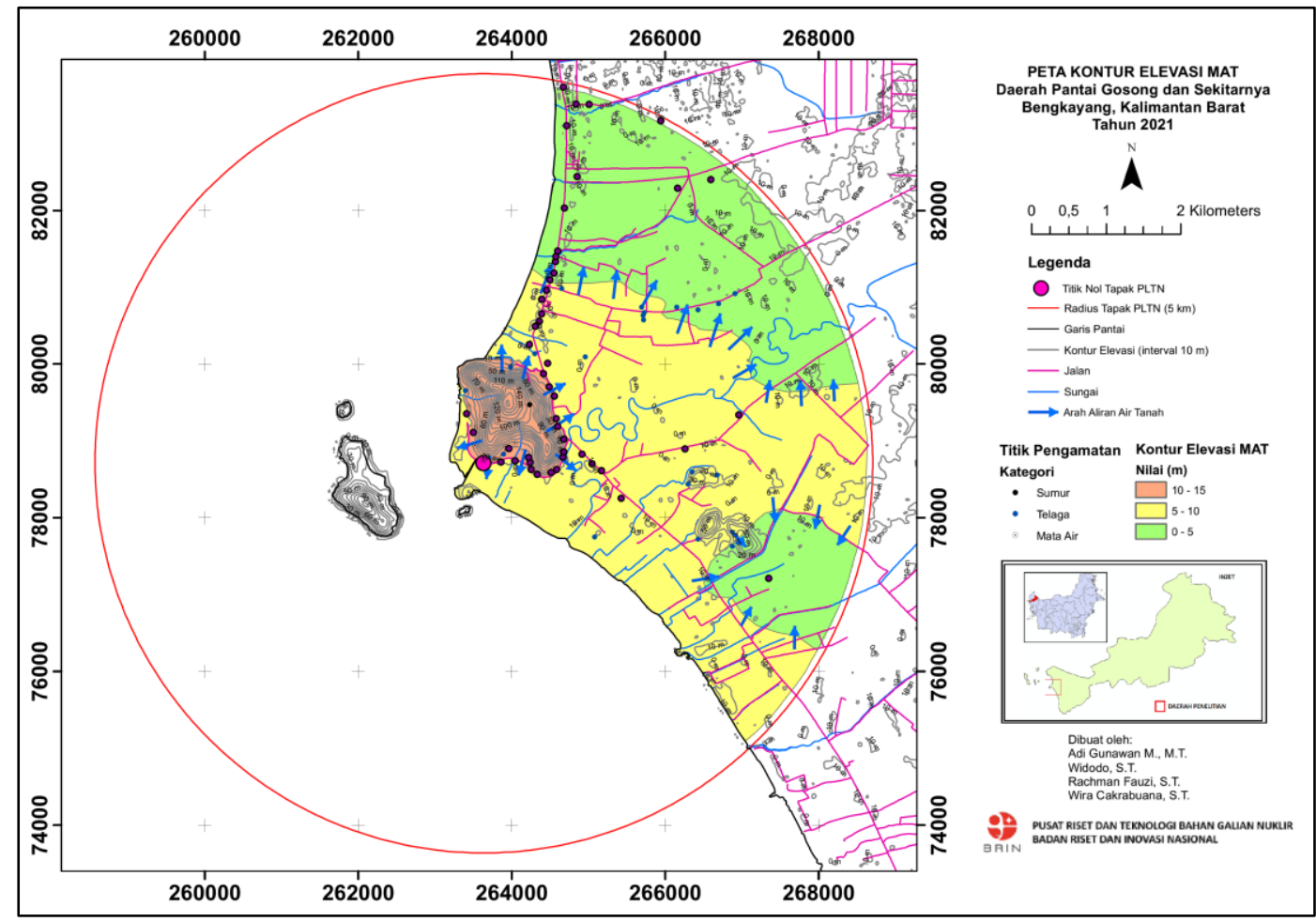

Gambar 11. Peta Kontur Elevasi MAT Daerah Penelitian

Berdasarkan Peta Kontur Elevasi MAT, wilayah potensi air tanah di lokasi ini sebagian besar terdapat di daerah dengan morfologi dataran dan perbukitan dengan akuifer yang tersusun atas endapan aluvial berupa lempung, pasir, kerikil, dan endapan pasir kuarsa. Potensi air tanah dengan jumlah terbatas dijumpai pada daerah lembah atau zona pelapukan batuan beku.

Berdasarkan pola relief morfologi permukaan, pengukuran MAT pada sumur dan mata air, tipe akuifer, serta elevasi MAT, dapat diinterpretasikan bahwa pola aliran tanah bebas pada area sekitar tapak PLTN mengalir relatif dari arah SSW ke NNE. Pola aliran air tanah tersebut secara lokal dipengaruhi oleh morfologi cekungan air tanah (CAT) yang akan mengalir dari elevasi akuifer tinggi ke rendah sehingga alur lepasan radionuklida (melalui proses dispersi) dalam air tanah diinterpretasikan akan memiliki pola relatif sama. 


\section{KESIMPULAN}

Hasil pemetaan geologi, pemetaan hidrogeologi, pengukuran geolistrik, dan analisis terpadu memberikan gambaran komprehensif terkait karakteristik akuifer di area sekitar calon tapak PLTN. Daerah penelitian secara geologi tersusun oleh batuan vulkanik andesit serta batuan terobosan diorit dan granodiorit yang tertutup oleh endapan pasir kuarsa, endapan aluvial dan endapan pantai. Satuan hidrogeologi terdiri atas akuifer dengan aliran antarbutir dengan kelulusan tinggi, akuifer dengan aliran antarbutir dengan kelulusan sedang, serta akuifug setempat berarti; dengan pola aliran tanah bebas mengalir relatif dari SSW ke NNE. Hasil penelitian ini diharapkan dapat menjadi acuan dalam studi tapak PLTN aspek geoteknik dan aspek dispersi zat radioaktif.

\section{UCAPAN TERIMA KASIH}

Penulis mengucapkan terima kasih kepada Lembaga Pengelola Dana Pendidikan (LPDP) serta Badan Riset dan Inovasi Nasional (BRIN) atas dukungan teknis dan finansial yang telah diberikan. Penulis juga mengucapkan terimakasih kepada Bapak Ir. Yarianto Sugeng Budi Susilo, M. Si. selaku Plt. Kepala Pusat Riset dan Teknologi Bahan Galian Nuklir serta Bapak Heri Syaeful, M.T. selaku Koordinator Bidang Eksplorasi yang telah mendukung penelitian ini sehingga dapat berjalan dengan lancar.

\section{DAFTAR PUSTAKA}

[1] F. N. Hussein et al., "Potensi Bahaya Gunung Api Terhadap Calon Tapak PLTN, Studi Kasus: Gunung Api Semadum, Kalimantan Barat," J. Pengemb. Energi Nukl., vol. 22, no. 2, hal. 89, 2020, doi: 10.17146/jpen.2020.22.2.6124.

[2] R. S. B. Waspodo, "Eksplorasi Potensi Air tanah pada Kawasan Industri Air Mineral Dalam Kemasan Cemplang, Bogor," J. Keteknikan Pertan., vol. 3, no. 2, hal. 22037, 2015, doi: 10.19028/jtep.03.2.
[3] A. Seijmonsbergen, M. G. G. de Jong, L. W. S. de Graaff, dan N. S. Anders, Geodiversität von Vorarlberg und Liechtenstein, no. June. Haupt, 2014.

[4] W. Lowrie, Fundamentals of Geophysics, 2 ed. Cambridge: Cambridge University Press, 2007.

[5] N. Herawati dan A. D. Sudagung, "Persepsi Masyarakat dan Potensi Public Acceptance Terkait Wacana Pembangunan PLTN di Kabupaten Bengkayang," J. Pengemb. Energi Nukl., vol. 22, no. 2, hal. 111, 2020, doi: 10.17146/jpen.2020.22.2.6125.

[6] H. Suntoko, "Identifikasi Daerah Interes Calon Tapak PLTN Kalimantan Barat Berdasarkan Kriteria Umum," Eksplorium Bul. Pus. Teknol. Bahan Galian Nukl., vol. 35, no. 1, hal. 57-68, 2014, doi: 10.17146/eksplorium.

[7] H. Susiati, "Penentuan Tapak Potensial PLTN dengan Metode SIG di Wilayah Pesisir Propinsi Kalimantan Barat," J. Pengemb. Energi Nukl., vol. 16, no. 2, hal. 131-142, 2014.

[8] R. Sahputra dan M. Rifat, "Studi Lokasi Untuk Pembangunan Pembangkit Listrik Tenaga Nuklir Berbasis Sistem Informasi Geografis di Kalimantan Barat," in Prosiding Semirata 2015 Bidang Teknologi Informasi dan Multi Disiplin, 2015, hal. 631-639.

[9] N. Suwarna dan R. P. Langford, Peta Geologi Lembar Singkawang, Kalimantan. Bandung, 1993.

[10] Zulfikar, S. Kaelani, dan D. Turdjaja, "Eksplorasi Umum Endapan Ball Clay di Kabupaten Bengkayang, Provinsi Kalimantan Barat,” 2007.

[11] H. Suntoko dan B. Soetopo, "Kajian Aspek Geologi dan Potensi Mineral Uranium di Kalimantan Barat Untuk Persiapan Pltn," J. Pengemb. Energi Nukl., vol. 15, no. 2, hal. 103114,2013

[12] W. Mudiana dan R. Hidayat, Peta Hidrogeologi Indonesia 1:250.000 Lembar Sambas dan Singkawang. Bandung: Direktorat Geologi Tata Lingkungan, 1984.

[13] N. Campos, L. M. Tanarro, dan D. Palacios, "Geomorphology of glaciated gorges in a granitic massif (Gredos range, central spain)," J. Maps, vol. 14, no. 2, hal. 321-329, 2018, doi: 10.1080/17445647.2018.1468829.

[14] J. O. Coker, "Vertical electrical sounding (VES) methods to delineate potential groundwater aquifers in Akobo area, Ibadan, South-western, Nigeria," J. Geol. Min. Res., vol. 4, no. 2, 2012, doi: 10.5897/jgmr11.014.

[15] A. G. Muhammad, F. D. Indrastomo, dan I. G. Sukadana, "Pola Resistivitas dan Konduktivitas Batuan Mengandung Mineral Radioaktif di Botteng dan Takandeang, Mamuju, Sulawesi Barat," Eksplorium, vol. 38, no. 1, hal. 49-62, 2017. 